\title{
PENDIDIKAN EKOWISATA PADA MASYARAKAT SEKITAR WISATA SUMBER MARON DESA KARANGSUKO
}

\author{
Zahwa Wulandari, Universitas Negeri Malang \\ zahwa.wulandari.1804316@students.um.ac.id \\ Sri Umi Mintarti, Universitas Negeri Malang \\ sri.umi.fe@um.ac.id \\ Agung Haryono, Universitas Negeri Malang \\ agung.haryono.fe@um.ac.id
}

\begin{abstract}
ABSTRAK
Kebutuhan pengunjung dalam berwisata saat ini tidak hanya berwisata tetapi mereka juga ingin mendapatkan pendidikan dari berwisata. Dewasa ini, masyarakat sekitar yang di daerahnya banyak potensi tidak bisa mengembangkan potensi dengan baik sesuai kebutuhan masyarakat atau pengunjung. Selain itu mereka juga tidak bisa memasarkan hasil pengembangan wisata di daerah mereka yang mengakibatkan wisata menjadi sepi pengunjung. Tujuan dari penelitian yang dilaksanakan untuk menambah wawasan ekowisata dan cara pemasarannya pada masyarakat sekitar, melihat efektifitas dalam pembelajaran yang telah dilaksanakan. Dalam penelitian ini, peneliti menggunakan penelitian pengembangan dengan metode Design Based Reseach. Penelitian didasarkan kebutuhan masyarakat sekitar wisata. Hasil menunjukkan bahwa modul yang dihasilkan sudah teruji kevalidan dan kemenarikannya serta pembelajaran yang dilakukan sudah efektif yang dibuktikan dengan rata-rata hasil latihan soal yang tinggi.
\end{abstract}

Kata Kunci: Ekowisata, Pendidikan Masyarakat, Pengembangan Modul.

\section{ABSTRACT}

The needs of tourists in traveling now are not only going, but they also want to get an education from traveling. Nowadays, the surrounding community, which has a lot of potential in the area, cannot develop the potential properly according to the needs of the community or visitors. Also, they could not market the results of tourism development in their area, which resulted in tourism being empty of visitors. The purpose of the research carried out is to add insight into ecotourism and how to market it to the surrounding community, looking at the effectiveness in the learning that has been carried out. In this study, researchers used research development with the Design-Based Research method. Research-based on the needs of the community around tourism. The results show that the modules produced have been tested for validity, and their attractiveness, as well as the learning that has been carried out, is useful, as evidenced by the high average results of the exercise questions.

Keywords: Ecotourism, Community Education, Module Development. 


\section{PENDAHULUAN}

Indonesia merupakan negara kepulauan yang memiliki keberagaman budaya dan potensi alam yang melimpah. Keberagaman tersebut apabila di kelola dengan tepat dan bijaksana akan memberikan dampak positif pada keberlangsungan hidup masyarakatnya. Saat ini pemerintah dengan berbagai pihak tengah gencar melakukan promosi "Pesona Indonesia" upaya ini dilakukan untuk menarik minat para wisatawan domestik dan internasional agar mau berkunjung dan berwisata ke beberapa daerah di Indonesia.

Upaya yang dilakukan oleh pemerintah bertujuan untuk menambah pendapatan negara maupun daerah yang diharapakan mampu meningkatkan kesejahteraan ekonomi masyarakatnya. Hal ini sejalan dengan pendapat (Josephine, Hardanti dan Hartono, 2015) adanya tempat wisata di suatu daerah tidak hanya meningkatkan perekonomian masyarakat, tetapi juga membuka lapangan pekerjaan baru bagi masyarakat sekitar, meningkatkan kesejahteraan masyarakat. Selain itu pariwisata juga membawa dampak baik seperti peningkatan devisa, memperluas lapangan pekerjaan, mendorong pembangunan daerah, peningkatan jumlah investasi (Surwiyanta, 2003).

Pengembangan potensi daerah seperti pembuatan tempat wisata tentu banyak pertimbangan yang harus dilakukan, salah satunya pengelolaan tempat wisata yang ramah lingkungan. Hal ini dilakukan untuk tetap menjaga kelestarian alam. Selain itu pembangunan wisata juga harus menerapkan sistem pembangunan berkelanjutan, agar masyarakat di masa mendatang tetap bisa menikmati apa yang kita nikmati sekarang adalah perwujudan dari ekowisata. Menurut (Situmorang dan Mirzanti, 2012) seseorang yang mengembangkan ekowisata harus mempunyai prinsip meminimalkan dampak, memberikan pengalaman positif, dan membangun kesadaran lingkungan dan berbudaya.

Menurut TIES atau The International Ecotourism Society dalam (Eshun, Adjei dan Segbefia, 2016) ekowisata adalah suatu perjalanan wisata ke wilayah alam yang bertujuan dalam rangka mengkonservasi alam atau menyelamatkan lingkungan dan bisa meningkatkan perekonomian lokal. Dalam pengembangan ekowisata, masyarakat atau pengunjung harus bisa meminimalkan dampak yang di keluarkannya.

Pariwisata sebagai salah satu pasar pariwisata yang cepat berkembang di dunia (Jamrozy dan Lawonk, 2017). Dewasa ini, masyarakat penikmat pariwisata juga sudah mulai sadar untuk mengunjungi daerah ekowisata. Pengunjung mulai tertarik dengan adanya konsep ekowisata karena mereka tidak hanya berwisata tetapi juga dapat belajar tentang pelestarian lingkungan. Selain itu, alasan masyarakat mengunjungi tempat ekowisata juga karena sudah mulai jenuh dan bosan mengunjungi wisata buatan. Jadi dalam ekowisata, semua yang terlibat sudah pasti mendapat manfaat. Seperti masyarakat sekitar ekowisata yang mendapatkan manfaat ekonomi dengan berjualan tetapi masih bisa menikmati keindahan alam desanya. Begitu juga pengunjung yang mendapat edukasi tentang hal menarik dan pengalaman baru dari perjalanan pariwisatanya.

Dalam pengembangan wisata di daerah sekitar dengan memanfaatkan potensi lokal, menurut (Kurniawati, Hamid dan Hakim, 2018) masyarakat sangat berperan penting dalam tahap awal hingga akhir seperti persiapan, 
perencanaan, operasional, pengembangan dan pengawasan. Masyarakat dalam mengembangkan wisata juga harus kreatif dan inovatif agar tempat mereka menarik dan banyak dikunjungi oleh masyarakat. Hal tersebut sesuai dengan (Undang-Undang Nomor 10, 2009) bahwa dalam berpariwisata atau menciptakan tempat wisata harus memperhatikan keunikan, keanekaragaman dan kekhasan budaya sekitar.

Adanya pariwisata yang khas dan kreatif menjadikan masyarakat sekitar mendapatkan banyak pengaruh. Pengaruh tersebut bisa berupa pengaruh budaya, ekonomi maupun sosial. Dampak ekonomi menurut (Hermawan, 2016) dari adanya pariwisata bagi masyarakat sekitar antara lain seperti penghasilan masyarakat meningkat, adanya peluang kerja dan berusaha, dan meningkatkan pendapatan pemerintah melalui retribusi. Jadi dengan adanya pariwisata yang dikembangkan di daerah sekitar, maka ekonomi masyarakat sekitar tidak akan tertinggal dengan daerah lain. Hal tersebut juga bisa menjadi solusi sebagai penghilangan stigma bahwa orang desa adalah orang miskin.

Untuk mengatasi permasalahan kesenjangan antara desa dan kota, Joko Widodo sebagai Presiden terpilih Indonesia tahun 2014-2019 mengeluarkan program Nawacita. Program tersebut salah satunya berisi tentang pembangunan Indonesia dari pinggiran dengan memperkuat desa. Program yang telah direncanakan tersebut diimplementasikan oleh Kementrian Pariwisata RI yaitu dengan mengembangkan destinasi wisata kelas dunia. Jawa Timur juga berupaya untuk mengambangkan wisata daerahnya dengan menggunakan slogan "Visit East Java" sebagai salah satu implikasinya dalam mengembangkan wisata yang ada di Jawa Timur. Pengembangan destinasi wisata tersebut adalah sebuah upaya untuk dari masyarakat, pengusaha dan pemerintah daerah (Undang-Undang Nomor 10, 2009).

Di setiap daerah di Jawa Timur juga memiliki slogan untuk memasarkan pariwisatanya kepada masyarakat. Jawa Timur memiliki banyak potensi lokal yang bagus dan sudah terkenal di seluruh dunia. Salah satu daerah yang memiliki potensi wisata local yang bagus adalah Kabupaten Malang. Kabupaten Malang dengan slogan "Malang The Heart of East Java". Kabupaten Malang memiliki potensi wisata yang bagus. Kabupaten Malang memiliki daya tarik sendiri bagi wisatawan karena di daerah tersebut ada banyak wisata seperti pantai, coban maupun gunung.

Kabupaten Malang juga memiliki sumber dikembangkan oleh masyarakat. Sumber tersebut berada di Kecamatan Pagelaran. Salah satu desa yang berpotensi dari adanya sumber tersebut yaitu daerah Desa Karangsuko. Di wisata sumber maron masyarakat bisa menikmati air terjun kecil yang menjadi ciri khas dari daerah tersebut. Wisata tersebut sudah banyak dikunjungi oleh masyarakat sekitar.

Wisata sumber maron sebelumnya hanyalah sumber digunakan untuk kegiatan sehari-hari seperti mandi, cuci baju, perairan sawah dan untuk sumber air bagi masyarakat sekitar. Setelah mendapat bantuan dari berbagai pihak untuk mengembangkan sumber air tersebut. Masyarakat mulai berbondongbondong untuk berkunjung ke sumber maron. Ada banyak keunikan yang dihasilkan dari pembangunan bantuan World Bank dan PLTMH (Pembangkit Listrik Tenaga Mikrohidro) salah satunya yaitu adanya bendungan kolam dan air terjun mini di sekitar sumber maron. Tidak hanya itu, masyarakat sekitar 
sumber maron juga bisa merasakan manfaatnya yaitu sumber mata air yang sebelumnya hanya untuk desa Karangsuko, sekarang bisa bertambah menjadi 4 desa yang memanfaatkan sumber air untuk kehidupan sehari-hari karena adanya PLTMH. Di wisata sumber maron, wisatawan bisa menikmati semilir angin sawah di sekitar sumber, air terjun dan bisa river turbing.

Dari identifikasi masalah yang telah dilakukan, ditemukan bahwa pengetahuan pengetahuan ekowisata yang dimiliki oleh masyarakat sekitar sumber maron untuk mengembangkan wisata masih kurang. Kurangnya pemahaman ekowisata pada masyarakat dibuktikan dengan banyaknya masyarakat di sekitar tempat wisata yang kurang menyadari adanya potensi lain yang bisa lebih dikembangkan lagi di sekitar tempat wisata sumber maron seperti oleh-oleh khas wisata, wisata berbasis edukasi di lahan pertanian yang menyediakan sarana bercocok tanam, dan fasilitas penunjuk jalan sebagai pedoman dalam mengakses ke wisata sumber maron.

Temuan lain dari hasil survey kepada para pengunjung juga ditemukan hasil bahwa mayoritas pengunjung berpendapat bahwa wahana yang ditawarkan di sumber maron dari dulu hingga sekarang tidak ada perubahan. Padahal dalam mengembangkan wisata dan dalam pemasaran didasarkan pada konsep kebutuhan, keinginan dan permintaan dari pengunjung (Kotler dan Amstrong, 2008). Masyarakat sekitar hanya menambah tempat berjualan saja dan tidak menambah wahana terbaru. Saat melakukan wawancara dengan masyarakat sekitar kenapa mereka tidak menambah wahana, mereka memberikan alasan bahwa mereka tidak memiliki ide atau kreatifitas lain selain berjualan.

Di sisi lain, warga sekitar sumber maron juga kesulitan dalam memasarkan kepada masyarakat luas tentang wisata sumber maron. Masyarakat mengetahui sumber maron hanya dari mulut ke mulut bukan dari internet. Dari omongan orang lain tersebut menjadikan pengunjung memiliki rasa ingin tahu untuk mengunjungi sumber maron. Tidak hanya dalam pemasaran, dalam mendirikan tempat berjualan, masyarakat juga mendirikannya di atas sawah. Hal tersebut bisa merusak sawah dan akhirnya sumber maron tidak bisa asri seperti semula. Padahal alih fungsi sawah tersebut sangatlah berbahaya karena masyarakat yang akan datang tidak bisa menikmati apa yang kita nikmati sekarang. Jika masyarakat tetap menggunakan sawah tersebut, kelestarian sumber maron akan hilang.

Pembangunan pariwisata yang selama ini sudah dilakukan oleh masyarakat sekitar memang sudah membawa dampak ekonomi terhadap masyarakat. Tetapi jika alih fungsi lahan dilakukan secara terus menerus akan membawa dampak buruk kedepannya. Untuk mengurangi dampak buruk yang telah dilakukan dan masalah bisa teratasi, cara yang perlu dilakukan yaitu dengan mengembangkan modul ekowisata yang berisi materi konsep ekowisata, cara pemasaran dan saran ekowisata yang bisa diterapkan di sumber maron. Adanya buku tersebut diharapkan bisa menambah wawasan masyarakat dan menjadi solusi dari permasalahan yang ada selama ini.

Pada kenyataannya, selama ini di sumber maron sendiri tidak pernah ada pemberian edukasi tentang ekowisata kepada masyarakat sekitar. Biasanya mereka hanya mendapatkan penyuluhan dari pemerintah yang hanya mendapatkan ilmu jika saat sosialisasi saja. Jadi saat mereka kembali ke rumah 
ilmu itu sudah hilang dan sosialisasi hanyalah formalitas saja. Padahal jika dilihat, pemberian modul sangatlah penting. Hal tersebut seperti hasil penelitian dari (Zulhariadi, 2018) dengan judul pengembangan bahan ajar berbasis riset pada mata kuliah ekowisata dengan tujuan untuk melihat potensi air terjun Tibu Bunter dan hal tersebut dijadikan dasar pengembangan bahan ajar. Hasil dari penelitian tersebut menunjukkan bahwa bahan ajar berupa modul yang telah dibuat secara keseluruhan teruji valid, layak dan efektif digunakan dalam kegiatan pembelajaran. Penilaian yang didapatkan oleh mahasiswa sebagai subjek uji coba juga menunjukkan nilai rata-rata yang di dapatkan yaitu 76,39 dengan kategori B.

Selain itu, dalam penelitian yang dilaksanakan oleh (Syafiudin, Sumarmi dan Astina, 2016) dengan judul pengembangan modul geografi pariwisata dengan project based learning untuk materi ekowisata pesisir dan laut di prodi S1 Pendidikan Geografi Universitas Negeri Malang hasilnya menunjukkan bahwa dengan adanya modul yang di kembangkan mahasiswa mampu memahami modul. Hasil nilai tes yang diberikan kepada mahasiswa pada rentan 85-100 dan dari angket yang diberikan menunjukkan 80\% mahasiswa menjawab bahwa modul yang dibuat layak untuk digunakan. Tujuan dari penelitiannya yaitu untuk mengembangkan modul geografi pariwisata.

Dari uraian permasalahan diatas, tujuan dari penelitian ini yaitu untuk mengembangkan modul ekowisata dan melihat keefektifan pembelajaran yang dilihat dari hasil latihan soal yang diberikan kepada masyarakat sekitar wisata sumber maron.

Bahan ajar berupa modul adalah suatu media yang digunakan dalam pembelajaran. Bahan ajar sendiri menurut (Mardetini dan Amrina, 2019) yaitu materi yang disajikan dalam pembelajaran dan di dalamnya berisi pengetahuan, sikap, nilai, keterampilan dan informasi. Selain berisi materi, bahan ajar digunakan untuk mencapai tujuan dari pembelajaran yang dilakukan. Di dalam bahan ajar biasanya ada 2 jenis yaitu cetak dan non cetak. Bahan ajar dengan jenis cetak bsa berupa modul yang di dalamnya berisi materi dan latihan soal. Handout sebagai bahan tertulis untuk memperkaya wawasan peserta. Dalam penelitian ini, bahan ajar yang digunakan berupa modul.

Pembuatan modul tersebut untuk memenuhi kebutuhan dari masyarakat sekitar wisata sumber maron. Penulis sebagai fasilitator atau pemberi materi yang akan menyampaikan isi materi secara singkat, hal tersebut untuk memberikan tantangan masyarakat agar belajar mandiri. Tidak hanya dituntut belajar mandiri, masyarakat juga harus bisa menjawab latihan soal yang diberikan oleh penulis. Latihan soal yang diberikan tersebut bertujuan untuk melihat apakah keefektifan pembelajaran sudah tercapai atau belum.

Desa Karangsuko yang memiliki potensi alam yang tidak diragukan lagi memang harus segera menerapkan ekowisata. Hal tersebut agar alam yang dimiliki desa tidak rusak, maka dari itu perlu adanya sosialisasi dengan pembuatan bahan ajar agar pemahaman masyarakat bisa lebih meningkat lagi dan kegiatan yang dilakukan tidak merusak lingkungan.

\section{METODE PENELITIAN}

Penelitian dan pengembangan ini menggunakan pendekatan Design 
Based Research (DBR) yang mengadopsi dari model pengembangan Peffer et al, (2007). Dalam penelitian ini bertujuan untuk menghasilkan modul dengan materi konsep ekowisata dan cara pemasaran pariwisata agar bisa meningkatkan kesejahteraan masyarakat sekitar dan menguji keefektifan pembelajaran dari modul yang telah dilaksanakan dan dibuat. Ada 6 fase pengembangan yang dilaksanakan oleh peneliti yaitu identifikasi masalah, perumusan produk, penyusunan desain, uji coba, evaluasi dan komunikasi.

Data yang diperlukan diperoleh dari data primer yaitu berupa wawancara, dokumentasi, kuisioner, dan lembar validasi. Wawancara berguna untuk memperoleh informasi awal tentang kebutuhan masyarakat, selain itu juga untuk mengetahui keefektifan pembelajaran. Kuisioner digunakan untuk mengetahui tingkat kemenarikan, isi dan materi modul yang digunakan dalam kegiatan pembelajaran. Lembar validasi untuk melihat kevalidan dari produk yang telah dibuat. Analisis data dalam penelitian ini yaitu analisis deskriptif kualitatif dan kuantitatif. Deskriptif kualitatif digunakan untuk mengolah data dan review subjek uji coba dengan pengelompokan informan data berupa tanggapan, kritik maupun saran pada lembar validasi dan hasil wawancara kepada peserta. Data kuantitatif digunakan untuk mengecek lembar validasi, nilai dan kuisioner.

\section{HASIL PENELITIAN DAN PEMBAHASAN}

Sumber maron merupakan salah satu tempat wisata di Desa Karangsuko Kecamatan Pagelaran Kabupaten Malang. Sumber maron merupakan tempat wisata air yang dahulu hanya digunakan untuk tempat kegiatan sehari-hari oleh warga tetapi sekarang digunakan untuk tempat wisata dan sebagai sumber mata air bagi 4 desa di sekitarnya. Sebagai tempat wisata alam air, sumber maron dikelilingi oleh sawah yang menjadi daya tarik bagi masyarakat sekitar untuk mengunjunginya.

Sumber maron adalah wana wisata edukasi, tetapi unsur edukasi belum muncul. Hal tersebut dibuktikan dengan masih banyaknya penjual yang mendirikan gubuk diatas sawah. Padahal sawah tersebut merupakan potensi yang dimiliki oleh desa. Semakin lama ada banyak sawah yang digunakan oleh warga sekitar untuk berjualan yang menjadikan sumber maron tidak asri lagi seperti dulu.

Padahal pengunjung yang mengunjungi sumber maron sekarang ini menginginkan wisata alam yang indah dengan pemanfaatan potensi yang dimiliki. Sumber maron memiliki potensi yang sangat bagus untuk dikembangkan. Potensi di sekitar sumber maron bisa dikembangkan untuk ekowisata. Jika sumber maron menjadi tempat ekowisata akan ada banyak manfaat yang di dapatkan. Manfaat yang akan di dapatkan dengan mengembangkan pariwisata yaitu adanya lapangan pekerjaan baru, meningkatkan ekonomi masyarakat dan dapat memberikan pemahaman tentang pariwisata serta pemanfaatan lingkungan berkelanjutan (Murianto, 2014).

Padahal pembangunan berkelanjutan sangatlah penting agar generasi yang mendatang bisa menikmati apa yang kita nikmati sekarang. Wisatawan sekarang ini menginginkan pariwisata yang di dalamnya ada unsur pendidikan, kebudayaan dan petualangan yang mereka dapatkan, dari pariwisata 
(Widagdyo, 2017). Jadi jika tidak dikembangkan secara baik dan mengikuti kebutuhan pengunjung maka sumber maron akan kelah dengan pariwisata lain yang bisa berkembang dengan baik. Dari hal tersebut, maka perlu pengembangan modul ekowisata untuk masyarakat sekitar wisata sumber maron.

Modul pendidikan ekowisata pada masyarakat sekitar sumber maron dikembangkan berdasarkan kebutuhan dan permasalahan yang terjadi sekarang ini. Pengembangan modul fokus pada permasalahan pengembangan ekowisata dan cara pemasaran sumber maron yang nantinya diharapkan bisa memberikan wawasan kepada masyarakat untuk mengembangkan sumber maron dan pemasarannya mengikuti perkembangan jaman.

Pengembangan pendidikan ekowisata ini di dalamnya memuat materi yang dibentuk modul pembelajaran sebagai bahan pembelajaran. Ukuran modul pendidikan ekowisata adalah $21.0 \mathrm{~cm}$ x $29,7 \mathrm{~cm}$ dan berjumlah 25 halaman. Ukuran tersebut sangat mempermudah pembaca dan 25 halaman sudah memuat informasi yang disajikan oleh peneliti dengan lengkap. Isi dalam modul tersebut yaitu penjelasan mengenai konsep ekowisata, cara pemasaran ekowisata dan contoh pengembangan ekowisata. Hal tersebut dibahas agar karang taruna dan masyarakat sekitar wisata Sumber Maron bisa lebih paham tentang ekowisata, bagaimana cara memasarkan produk yang telah mereka hasilkan dan wahana apa yang akan di kembangkan di sumber maron nantinya. Visualisasi cover bisa di lihat di gambar 1. dan layout isi sebagai di gambar 2.

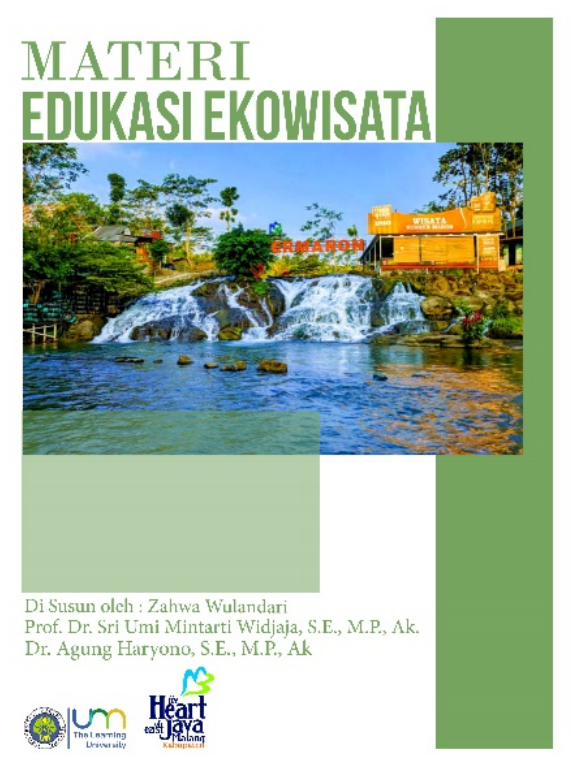

Gambar 1. Cover Modul

Pembuatan modul berangkat dari kebutuhan dan permasalahan yang ada di sumber maron. Kebutuhan dan permasalahan yang ada di sumber maron yaitu kurangnya kreatifitas dan pendidikan tentang ekowisata yang dimiliki masyarakat masih belum ada. Selain itu masyarakat tidak bisa memasarkan hasil pengembangan wisata mereka dengan baik. Dari hal tersebut maka perlu pemberian modul kepada masyarakat. 

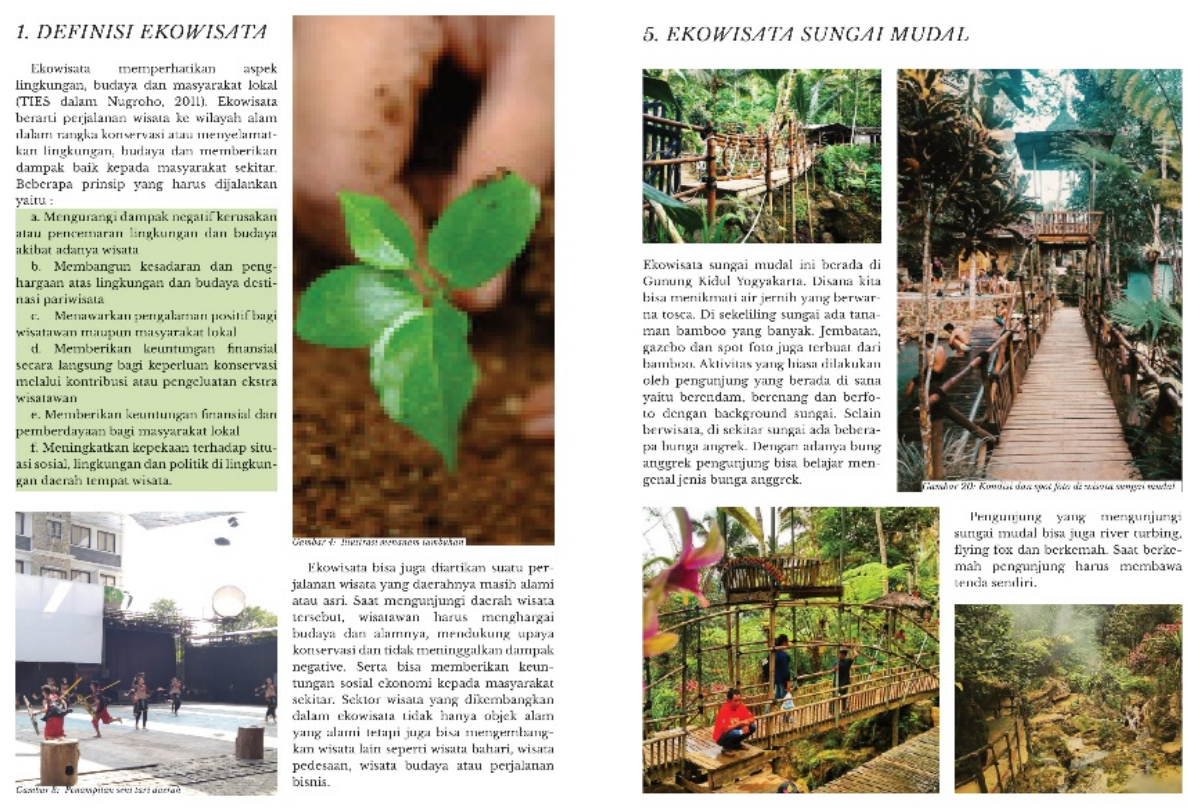

Gambar 2. Sampel Isi dan Materi Modul

Adanya modul diharapkan agar sumber maron bisa menjadi lebih baik lagi dari sebelumnya. Selain itu, pengembangan tersebut juga akan menambah pendapatan masyarakat sekitar sebab masyarakat akan lebih tertarik mengunjungi sumber maron karena pengembangan yang telah dilakukan. Jika pengunjung meningkat maka penjualan makanan juga akan meningkat.

Sebelum di uji cobakan kepada masyarakat, modul yang dibuat tersebut di uji kevalidannya oleh para tim ahli. Dalam penilaian, ada beberapa kriteria yang digunakan. Kriteria penilaian yang digunakan dalam penilaian yaitu:

Tabel 1. Kriteria kevalidan

\begin{tabular}{llll}
\hline No & Presentase & Kualifikasi & Keterangan \\
\hline 1 & $85 \%-100 \%$ & Sangat Baik & $\begin{array}{l}\text { Tidak perlu } \\
\text { direvisi }\end{array}$ \\
2 & $75 \%-84 \%$ & Baik & $\begin{array}{l}\text { Tidak perlu } \\
\text { direvisi }\end{array}$ \\
3 & $65 \%-74 \%$ & Cukup & Direvisi \\
4 & $55 \%-64 \%$ & Kurang & Direvisi \\
5 & $0 \%-54 \%$ & Kurang sekali & Direvisi \\
\hline
\end{tabular}

Dengan perhitungan rumus skor $=$ jumlah penilaian ahli/skor ideal $\mathrm{x} 100$ $\%$ uji validitas dilakukan pada tim ahli yang terdiri dari ahli materi, ahli lapangan dan ahli media. Hasil validasi dari ketiga tim ahli disajikan di tabel 2 sampai 4. Tabel 2 merupakan ringkasaan uji validasi ahli materi. Tabel 3 
adalah hasil validasi ahli lapangan. Sedangkan Tabel 4 menyajikan uji validasi ahli media.

Tabel 2. Uji validasi ahli materi

\begin{tabular}{ccccl}
\hline No & $\begin{array}{c}\text { Aspek yang } \\
\text { Dinilai }\end{array}$ & $\begin{array}{c}\text { Skor } \\
\text { Ideal }\end{array}$ & $\begin{array}{c}\text { Jumlah } \\
\text { Penilaian Ahli }\end{array}$ & \multicolumn{1}{c}{ Revisi } \\
\hline 1 & Kegunaan & 16 & 15 & Materi sudah jelas \\
2 & Kelayakan & 12 & 12 & tetapi perlu \\
3 & Kemenarikan & 20 & 18 & dilengkapi dengan \\
4 & Bahasa & 16 & 16 & evaluasi soal untuk \\
5 & Kejelasan & 16 & 15 & mengetahui hasil \\
& Total & $\mathbf{8 0}$ & $\mathbf{7 6}$ & edukasi. \\
\hline
\end{tabular}

Skor $=76 / 80 \times 100=95 \%$

Tabel 3. Uji validasi ahli lapangan

\begin{tabular}{ccccl}
\hline No & $\begin{array}{c}\text { Aspek yang } \\
\text { Dinilai }\end{array}$ & $\begin{array}{c}\text { Skor } \\
\text { Ideal }\end{array}$ & $\begin{array}{c}\text { Jumlah } \\
\text { Penilaian Ahli }\end{array}$ & \multicolumn{1}{c}{ Revisi } \\
\hline 1 & Kegunaan & 16 & 15 & Contoh ekowisata \\
2 & Kelayakan & 12 & 11 & yang bisa diterapkan \\
3 & Kemenarikan & 20 & 18 & di Sumber Maron \\
4 & Bahasa & 16 & 16 & harus jelas dan \\
5 & Kejelasan & 16 & 15 & sesuai dengan \\
& Total & $\mathbf{8 0}$ & $\mathbf{7 5}$ & kondisi di lapangan \\
\hline
\end{tabular}

Skor $=75 / 80 \times 100=93,75 \%$

Tabel 4. Uji validasi ahli media

\begin{tabular}{ccccl}
\hline No & $\begin{array}{c}\text { Aspek yang } \\
\text { Dinilai }\end{array}$ & $\begin{array}{c}\text { Skor } \\
\text { Ideal }\end{array}$ & $\begin{array}{c}\text { Jumlah } \\
\text { Penilaian Ahli }\end{array}$ & \multicolumn{1}{c}{ Revisi } \\
\hline 1 & Cover & 16 & 14 & Sumber \\
2 & Bahasa & 16 & 15 & pembelajaran dalam \\
3 & Penyajian Buku & 20 & 18 & skenario sesuaikan \\
4 & Kegunaan & 16 & 15 & dengan tujuan \\
5 & Kelayakan & 12 & 11 & pembuatan materi \\
& Total & $\mathbf{8 0}$ & $\mathbf{7 3}$ & edukasi. \\
\hline
\end{tabular}

Skor $=73 / 80 \times 100=91,25 \%$

Validasi dari tim ahli menunjukkan bahwa skor yang diperoleh sudah diatas $85 \%$ yang menunjukkan tidak perlu adanya revisi tetapi ada beberapa perbaikan. Setelah uji coba modul, ada tindak lanjut yang dilaksanakan melalui kegiatan pemberian angket sebagai respon para masyarakat yang menjadi peserta pelatihan. Angket digunakan untuk mengetahui kemenarikan isi dan materi dalam bahan ajar yang telah dibuat, nantinya dari angket bisa mengetahui perbaikan atau kekurangan dari bahan ajar tersebut. Dalam pelaksanaan, peserta pelatihan yaitu berumur 20-40 tahun yang dimana umur 
tersebut adalah golden age dan memiliki kematangan dalam hal apapun (Hiryanto, 2017).

Setelah melakukan validasi, peneliti melaksanakan penelitian. Dari penelitian yang telah dilaksanakan, peneliti mendapat beberapa temuan yaitu tanggapan peserta yang diperoleh dari angket, hasil post test, dan komentar peserta terhadap pembelajaran. Hasil angket tersebut disajikan di tabel 5.

Tabel 5. Hasil Tanggapan Peserta Kegiatan Pembelajaran Ekowisata

\begin{tabular}{|c|c|c|c|c|c|}
\hline \multirow[b]{2}{*}{ No. } & \multirow[b]{2}{*}{$\begin{array}{c}\text { Indikator } \\
\text { pengukuran }\end{array}$} & \multirow[b]{2}{*}{ Komponen yang ditanggapi } & \multicolumn{3}{|c|}{ Tanggapan (\%) } \\
\hline & & & Ya & Tidak & $\begin{array}{l}\text { Tidak } \\
\text { Tahu }\end{array}$ \\
\hline \multirow[t]{7}{*}{1} & Reaksi Peserta & $\begin{array}{l}\text { Apakah pembelajaran yang dilakukan } \\
\text { menyenangkan? }\end{array}$ & 100 & 0 & \\
\hline & & $\begin{array}{l}\text { Apakah pembelajaran yang dilakukan } \\
\text { menarik untuk dipelajari? }\end{array}$ & 100 & 0 & \\
\hline & & $\begin{array}{l}\text { Apakah waktu yang disediakan untuk } \\
\text { kegiatan pembelajaran cukup? }\end{array}$ & 81,25 & 18,75 & \\
\hline & & $\begin{array}{l}\text { Apakah media yang digunakan dapat } \\
\text { dipahami dan menarik? }\end{array}$ & 87,5 & 12,5 & \\
\hline & & $\begin{array}{l}\text { Apakah peserta termotivasi untuk } \\
\text { mengikuti kegiatan pembelajaran? }\end{array}$ & 93,75 & 6,25 & \\
\hline & & $\begin{array}{l}\text { Apakah bahasa yang digunakan di } \\
\text { dalam materi pembelajaran mudah } \\
\text { dipahami dan komunikatif? }\end{array}$ & 100 & 0 & \\
\hline & & $\begin{array}{l}\text { Apakah ilustrasi yang digunakan sesuai } \\
\text { dengan materi yang dipelajari? }\end{array}$ & 93,75 & 6,25 & \\
\hline \multirow[t]{3}{*}{2} & Proses Belajar & $\begin{array}{l}\text { Apakah materi dalam pembelajaran } \\
\text { mudah dipahami? }\end{array}$ & 100 & 0 & \\
\hline & & $\begin{array}{l}\text { Setelah mengikuti pembelajaran, } \\
\text { apakah peserta mendapatkan } \\
\text { pengetahuan yang diajarkan? }\end{array}$ & 100 & 0 & \\
\hline & & $\begin{array}{l}\text { Setelah mengikuti pembelajaran, } \\
\text { apakah peserta memiliki kemauan } \\
\text { untuk menerapkan materi yang } \\
\text { diajarkan? }\end{array}$ & 100 & 0 & \\
\hline \multicolumn{2}{|c|}{ Komentar/Saran } & & & & \\
\hline
\end{tabular}

Angket yang digunakan untuk melihat kemenarikan isi dan materi. Hasil dari angket tersebut menunjukkan bahwa dalam pembelajaran isi dan materi yang ada menarik dan mudah di pahami. Beberapa aspek yang ada di angket mendapatkan prosentase $100 \%$ yang artinya setuju. Prosentase dengan hasil bawah sendiri yaitu tentang waktu, bebebrapa orang menginginkan waktu yang lama. Di dalam kolom komentar beberapa dari mereka menuliskan bahwa modul yang dibuat sudah menarik dan perlu adanya sosialisasi lebih lanjut lagi agar lebih semangat mengembangkan sumber maron. Dari komentar, angket dan uji validasi tersebut membuktikan bahwa modul yang dibuat sudah teruji valid dan menarik menurut tim ahli dan subjek uji coba.

Selain angket, peneliti juga mendapatkan hasil post test yang digunakan untuk melihat keefektifan pembelajaran yang diringkas di tabel 6 . Hasil post test tersebut menunjukkan bahwa ada beberapa nilai peserta yang sudah mendapat predikat baik dan beberapa peserta mendapatkan nilai sempurna. Rata-rata hasil nilai post tes yaitu 89,3 . Hal tersebut menunjukkan bahwa 
pembelajaran yang dilakukan sangat efektif dan bisa menambah pemahaman peserta. Hasil temuan penelitian tersebut sejalan dengan penelitian yang dilakukan oleh (Lasmiyati dan Harta, 2014) bahwa modul bisa meningkatkan pemahaman peserta didik yang diajar. Temuan lain dalam penelitian (Trisnawati, Wahyono dan Wardoyo, 2018) juga menunjukkan bahwa dengan adanya modul pelatihan yang dilaksanakan menjadi efektif. Dalam prakteknya, adanya modul bisa membuat pembelajaran menjadi efektif dan menjadikan masyarakat memahami konsep ekowisata. Jika hal tersebut dilakukan maka sumber maron akan memberikan banyak manfaat yang baik bagi kehidupan di masa mendatang.

Tabel 6. Rincian nilai hasil pembelajaran

\begin{tabular}{llr}
\hline No & Nama & Nilai \\
\hline 1 & Lailatul Hamidah & 100 \\
2 & Nur Laila & 100 \\
3 & Slamet & 80 \\
4 & Dwi Adi Putra & 90 \\
5 & Irfan & 100 \\
6 & Ubid & 100 \\
7 & Zainul & 80 \\
8 & Wahyu Syahputra & 80 \\
9 & Sabita Ulawiyatus & 100 \\
10 & Tamim & 90 \\
11 & Yain & 90 \\
12 & Nanda Eka & 80 \\
13 & Wiyono & 80 \\
14 & Lia & 90 \\
15 & Sumiati & 80 \\
\hline
\end{tabular}

Manfaat yang didapatkan oleh masyarakat saat mengembangkan ekowisata menurut Yoeti dalam (Hijriati dan Mardiana, 2015) yaitu meningkatkan pendapatan masyarakat dan meningkatkan lapangan pekerjaan. Selain itu dengan pengembangan ekowisata juga bisa membuat lingkungan di sekitar lebih asri. Tidak hanya dilihat dari hasil post test, dalam wawancara yang dilakukan kepada masyarakat menunjukkan bahwa mereka banyak mendapatkan pengetahuan dan wawasan dari pembelajaran yang dilaksanan. Nantinya mereka juga ingin membagikan ilmu tersebut kepada warga lain secara perlahan. Dari hasil tersebut menunjukkan bahwa pembelajaran modul pendidikan ekowisata yang telah dilaksanakan sudah efektif.

Dampak yang ditimbulkan dari pembelajaran yang telah dilakukan sudah mulai terlihat. Masyarakat sudah menjadikan daerah sekitar wisatanya lebih asri lagi dari sebelumnya dengan menanam tumbuhan di sekitar jalan menuju wana wisata. Selain itu, saran dalam modul yang dibuat juga sudah mulai diterapkan, seperti masyarakat sudah mulai membersihkan rumah untuk mendirikan homestay yang akan ditawarkan untuk para wisatawan yang berkunjung dan menginap. Saran lain yang sudah mulai dijalankan yaitu dengan penambahan spot foto di sekitar wisata, paket wisata dan wisata edukasi juga sudah mulai direncakana dan akan segera di promosikan oleh para pengelola wisata. Promosi yang sebelumnya tidak pernah dilakukan sekarang 
sudah mulai digencarkan seperti memperbarui isi web. Dalam pemasaran tidak hanya menggunakan web tetapi juga menggunakan media sosial untuk menarik minat pengunjung. Media sosial digunakan karena digunakan oleh semua kalangan masyarakat, dengan begitu akan mempercepat proses pemasaran yang dilakukan. Rencananya, web dan media sosial tersebut bisa untuk memesan tiket, homestay maupun paket wisata yang ditawarkan.

\section{SIMPULAN}

Berdasarkan hasil yang telah dicapai pada pengembangan yang telah dilaksanakan, tujuan pengembangan telah terjawab, yakni: 1) Modul pendidikan ekowisata teruji valid dan menarik bagi masyarakat sekitar sumber maron, hal tersebut dilihat dari hasil uji validitas dan pemberaian angket kepada masyarakat; 2) Efektifitas dari modul yang sudah dibuat juga sudah terjawab yang dilihat dari hasil post test dan wawancara kepada masyarakat

Adapun kelebihan dari pengemangan modul ekowisata adalah sebagai berikut. Pertama, modul pengembangan pendidikan ekowisata disusun berdasarkan kebutuhan peserta di Desa Karangsuko yang memiliki pengetahuan pendidikan ekowisata yang kurang sehingga modul pendidikan ekowisata sangat efektif untuk meningkatkan pengetahuan peserta pelatihan. Kedua, model pelatihan yang diajarkan juga berguna untuk meningkatkan kemampuan dalam mengaplikasikan dalam kehidupan sehari-hari dan kehidupan yang akan datang. Ketiga, produk model pelatihan pengembangan pendidikan ekowisata memiliki tingkat validasi yang memenuhi syarat untuk digunakan dalam pelatihan yang sesungguhnya karena telah diuji validasi oleh tim ahli dan pemberian angket kepada subjek uji coba. Kelima, implementasi produk membantu membangun dan mengembangkan desa sesuai dengan kebijakan pemerintah saat ini dalam membangun desa.

Modul yang sudah dikembangkan diharapkan bisa diterapkan di daerah lain yang memiliki potensi wisata yang bagus. Pengembangan moduk juga di modifikasi dengan materi lainnya yang diharapkan bisa menambah wawasan masyarakat. Selain itu, modul pembelajaran yang ada juga bisa dibuat dalam bentuk e-book.

\section{DAFTAR RUJUKAN}

Eshun, G., Adjei, P. O. dan Segbefia, A. Y. (2016) “" Beyond Business as Usual ': Implications of Tourist Experiences for Ecotourism Development," 5(2), hal. 1-26.

Hermawan, H. (2016) "Dampak Pengembangan Desa Wisata Nglanggeran Terhadap Ekonomi Masyarakat Lokal," Jurnal Pariwisata, 3(2), hal. $105-117$.

Hijriati, E. dan Mardiana, R. (2015) "Pengaruh Ekowisata Berbasis Masyarakat Terhadap Perubahan Kondisi Ekologi, Sosial dan Ekonomi di Kampung Batusuhunan, Sukabumi," Sodality: Jurnal Sosiologi Pedesaan. doi: 10.22500/sodality.v2i3.9422. 
Hiryanto (2017) “- 65 Hiryanto,” Dinamika Pendidikan, 22.

Jamrozy, U. dan Lawonk, K. (2017) "The multiple dimensions of consumption values in ecotourism," International Journal of Culture, Tourism, and Hospitality Research, 11(1), hal. 18-34. doi: 10.1108/IJCTHR-09-20150114.

Josephine, W., Hardanti, Y. R. dan Hartono, L. B. (2015) Kehidupan Ekonomi Dan Sosial Masyarakat, Wuri, Josephine dkk, 2015, Dampak Keberadaan Kampung Wisata terhadap Kehidupan Ekonomi dan Sosial Masyarakat. doi: Jurnal Penelitian.

Kotler dan Amstrong (2008) Prinsip-Prinsip Pemasaran Jilid I, Erlangga.

Kurniawati, E., Hamid, D. dan Hakim, L. (2018) "Peran Masyarakat dalam Perencanaan dan Pengembangan Desa Wisata Tulungejo Kecamatan Bumiaji Kota Batu," Jurnal Administrasi Bisnis (JAB), 54(1), hal. 8-14. Tersedia pada: administrasibisnis.studentjournal.ub.ac.id\%0A8.

Mardetini, E. dan Amrina, D. E. (2019) "Pengembangan Buku Ajar Analisis Laporan Keuangan Berbasis Problem Based Learning," Journal Ekonomi Pendidikan dan Kewirausahaan, 7(2), hal. 111-128. doi: 10.26740/jepk.v7n2.p111-128.

Murianto, M. (2014) "Potensi Dan Persepsi Masyarakat Serta Wisatawan Terhadap Pengembangan Ekowisata di Desa Aik Berik, Lombok Tengah," Jurnal Master Pariwisata (JUMPA). doi: 10.24843/jumpa.2014.v01.i01.p03.

Peffers, K. et al. (2007) "A design science research methodology for information systems research," Journal of Management Information Systems, 24(3), hal. 45-77. doi: 10.2753/MIS0742-1222240302.

Situmorang, D. B. M. dan Mirzanti, I. R. (2012) "Social Entrepreneurship to Develop Ecotourism," Procedia Economics and Finance. The Authors, 4(Icsmed), hal. 398-405. doi: 10.1016/s2212-5671(12)00354-1.

Surwiyanta, A. (2003) "Dampak pengembangan pariwisata terhadap kehidupan budaya dan ekonomi," Media Wisata, hal. 33-42.

Syafiudin, M., Sumarmi, S. dan Astina, I. (2016) "Pengembangan Modul Geografi Pariwisata Dengan Project Based Learning Untuk Materi Ekowisata Pesisir dan Laut di Program Studi S1 Pendidikan Geografi Universitas Negeri Malang," Jurnal Pendidikan - Teori, Penelitian, dan Pengembangan. doi: 10.17977/jp.v1i3.6160. 
Trisnawati, A. E., Wahyono, H. dan Wardoyo, C. (2018) "Pengembangan Desa Wisata dan Pemberdayaan Masyarakat Berbasis Potensi Lokal," Jurnal Pendidikan: Teori, Penelitian, dan Pengembangan, 3(1), hal. 29-33. doi: 10.17977/JPTPP.V3I1.10356.

Undang-Undang Nomor 10 (2009) "Undang-Undang Nomor 10 Tahun 2009 Tentang Kepariwisataan,” UU No 102009.

Widagdyo, K. G. (2017) "Pemasaran, Daya Tarik Ekowisata, dan Minat Berkunjung Wisatawan," Esensi: Jurnal Bisnis dan Manajemen. doi: 10.15408/ess.v7i2.5411.

Zulhariadi, R. D. K. dan M. (2018) "1,2 1 \& 2," in R, D. K. dan Muhammad, Z. (ed.) Pengembangan Bahan Ajar Berbasis Riset pada Matakuliah Ekowisata. Mataram, hal. 375-380. Tersedia pada: http://download. garuda.ristekdikti.go.id/article.php? article $=971888 \& v a l=14957 \&$ title $=\mathrm{Pe}$ ngembangan Bahan Ajar Berbasis Riset pada Matakuliah Ekowisata. 